\title{
Commentary
}

\section{Polymorphs, Proteins, and Nucleation Theory: A Critical Analysis}

\author{
John Spencer Evans \\ Department of Basic Sciences, Skeletal Biology and Craniofacial Medicine, New York University, \\ 345 E. 24th Street, New York, NY 10010, USA; jse1@nyu.edu; Tel.: +1-212-998-9605 \\ Academic Editor: Denis Gebauer \\ Received: 1 April 2017; Accepted: 18 April 2017; Published: 21 April 2017
}

\begin{abstract}
Over the last eight years new theories regarding nucleation, crystal growth, and polymorphism have emerged. Many of these theories were developed in response to observations in nature, where classical nucleation theory failed to account for amorphous mineral precursors, phases, and particle assembly processes that are responsible for the formation of invertebrate mineralized skeletal elements, such as the mollusk shell nacre layer (aragonite polymorph) and the sea urchin spicule (calcite polymorph). Here, we summarize these existing nucleation theories and place them within the context of what we know about biomineralization proteins, which are likely participants in the management of mineral precursor formation, stabilization, and assembly into polymorphs. With few exceptions, much of the protein literature confirms that polymorph-specific proteins, such as those from mollusk shell nacre aragonite, can promote polymorph formation. However, past studies fail to provide important mechanistic insights into this process, owing to variations in techniques, methodologies, and the lack of standardization in mineral assay experimentation. We propose that the way forward past this roadblock is for the protein community to adopt standardized nucleation assays and approaches that are compatible with current and emerging nucleation precursor studies. This will allow cross-comparisons, kinetic observations, and hopefully provide the information that will explain how proteins manage polymorph formation and stabilization.
\end{abstract}

Keywords: polymorphs; sea urchin; mollusk; calcite; vaterite; aragonite; biomineralization; proteins; classical nucleation theory; crystallization by particle attachment; non-classical nucleation

\section{Introduction}

In nature, invertebrate organisms primarily utilize calcium carbonates as the building materials for extracellular skeletal elements such as the mollusk shell [1-4] sea urchin spicules [5-11] and corals [12-14]. Biological calcium carbonates can exist in an amorphous state (amorphous calcium carbonate, ACC) [9-11,15-19] and as three different crystalline polymorphs: calcite, aragonite, and vaterite, where calcite is the more stable form and aragonite and vaterite are metastable relative to calcite $[15,16]$. Polymorphism, or the ability of a solid to exist in more than one lattice structure [15,16,20], is a feature of both naturally-occurring and artificial compounds [15-24]. Thus, the study of polymorphism in invertebrate skeletal elements can provide important insights into polymorph formation and stabilization over a wide range of conditions.

The attraction of biological calcium carbonate polymorphism to the scientific community is that this process occurs largely under ambient conditions [1-19] and thus represents a "game changer" for materials science and chemistry communities who have utilized non-ambient and sometimes extreme conditions to generate a given polymorph. What is often overlooked in the discussion of biological calcium carbonate polymorphism is the role and identity of extrinsic agents in the formation and stabilization processes. For example, the literature shows that extrinsic agents such as alcohols [21], 
gels [22,23], and $\mathrm{Mg}$ (II) ions [24] can foster metastable aragonite formation instead of calcite in vitro. Thus, we might assume that in biological organisms, polymorph stabilizing or promoting agents may exist as well. Some examples would include $\mathrm{Mg}(\mathrm{II})$, which is present in a 5:1 ratio relative to $\mathrm{Ca}(\mathrm{II})$ in seawater [24], or, small molecule metabolic end products, such as phosphate, which have been shown to stable ACC [25].

We must, however, also acknowledge that invertebrate skeletal elements are composite structures consisting of the mineral phase(s) and macromolecular components [1-14]. Here, the mineral phase nucleates and matures within this matrix. Therefore the potential role of matrix macromolecules such as proteins looms large in polymorphism. If proteins do play a role in calcium carbonate polymorph selection and stabilization, then this process must fall under genomic and proteomic guidance [5-8,13,14,26-28]. Hence, polymorphism could be controlled by the temporal, spatial, and quantitative aspects of protein components within the extracellular space. If true, then the scientific community could avail itself of this tremendous molecular variation to guide a given polymorph to form, possibly with higher efficiency and purity at the endpoint that present capabilities do not allow.

The intent of this review is to "jumpstart" the discussion of protein-mediated polymorphism as it pertains to invertebrate calcium carbonate skeletal elements alone in the absence of additives such as $\mathrm{Mg}(\mathrm{II})$. In other words, do proteins possess the inherent capabilities to direct specific polymorph formation without the assistance of other agents? Admittedly, scientific progress and understanding in this area have been slow, primarily due to two factors: first, our understanding of the nucleation process is still undergoing evolution and testing, and within the last few years alternatives to classical nucleation theory have emerged [15,16,29-33], which will be discussed in the next section. Thus, the challenge is to figure out where in these schemes aragonite, calcite, and vaterite-specific proteins might avail themselves to manipulate and regulate the nucleation and polymorph selection process. Second, and perhaps most importantly, genomic and proteomic studies of biomineralization proteins have uncovered a vast repertory of proteins $[6-8,13,14,26-28]$ that could potentially manage many aspects of proposed nucleation processes, including polymorphism. However, although many protein studies have confirmed that polymorphs do form when proteins are present [34-53], these studies have not provided information that is needed for detailing the mechanisms of polymorph formation, or, have utilized a variety of testing methods that prevent cross-comparisons of datasets necessary for mechanism building [34-53]. Here, we believe that the challenge for the protein community will be to adopt consistent mineralization assay standards and approaches that are compatible with current and emergent nucleation precursor studies [15,16,29-33]. These studies will allow time-dependent, careful monitoring of protein effects on the early events in nucleation and polymorph selection processes that can yield information on mechanisms. Only then will we be able to determine what nucleation schemes are at work in nature, how proteins foster polymorph formation and stabilization, and how to apply this information to materials science.

\section{The Current State of Knowledge Regarding Nucleation and Polymorph Formation}

In terms of classical nucleation theory, polymorph formation is a process dictated by thermodynamic and kinetics factors, where monomer-by monomer addition to an isolated ordered cluster results in a crystal with a given lattice structure (Figure 1) [15,16,29,54]. In the classical scheme polymorph selection is thus determined by the correct combination of polymorph-specific thermodynamic (e.g., temperature, pressure, volume) and kinetic (i.e., timeline or rate) factors which lower the nucleation energy barrier to crystal formation [54]. Hypothetically, this process could be managed by agents or additives in many ways to lower the energy barrier for nucleation and generate the appropriately structured cluster that would subsequently grow into a specific polymorph via monomer-by-monomer addition $[15,16,29,54]$. In laboratory practice, however, there is sometimes a lack of efficiency in generating a desired polymorph by simply manipulating these factors, and this leads to the formation of undesired polymorphs as impurities [20]. 


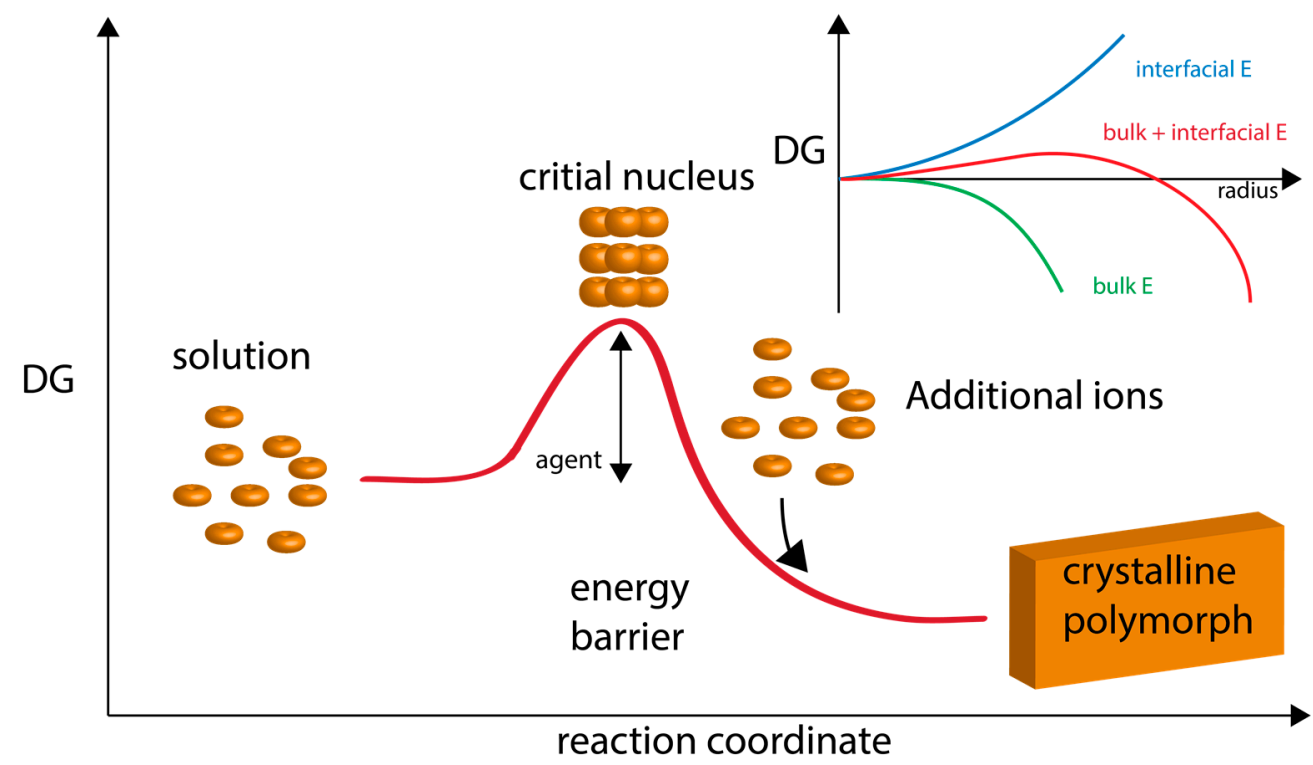

Figure 1. Graphical representation of classical nucleation theory and polymorph formation. Here, ions attain a concentration level (supersaturation) which fosters the formation of a critical nucleus. This nucleus then continues to growth via ion apposition at interfaces. "Energy barrier" refers to the energy of nucleation. "Agent" refers to additives, such as proteins, that would lower the nucleation energy barrier and foster polymorph formation and stabilization. The inset graph describes the formation of nuclei in supersaturated homogeneous solution, which is governed by the balance between the bulk and surface energy of the new phase. The point at which the bulk contribution compensates for the energetic costs arising from the interfacial surface is referred to as the critical size. Thermodynamically, the critical size reflects a metastable state since any infinitesimal change towards either smaller or larger radii will render the system unstable and lead to nucleus dissolution or unlimited growth, respectively. Adapted from references $[15,16,54]$.

As usual, in nature, things are not always so straightforward. One of the most dramatic observations is that prior to the crystallization event, organisms first form an amorphous precursor, ACC, which then transforms into a given crystalline calcium carbonate polymorph [9-11,15-19].

Here, the nucleation of ACC takes place at concentrations lower than those necessitated by classical theory and the monomer addition process $[15,16,29,54]$. This is compounded by another important observation that is clearly inconsistent with classical nucleation theory [54]: the formation of mineralized tissues, such as mollusk shell nacre [1-4] or sea urchin spicules [5-11] occurs via the assembly of individual mineral nanoparticles into mesoscale structures, rather than by monomer-by-monomer addition. Thus, we must either look outside or amend classical nucleation theory to describe applicable mechanisms that explain biological ACC formation and subsequent crystal growth. In doing so, we stand a good chance of developing new laboratory processes for practical polymorph selection that are more efficient.

Owing to the complexity of the extracellular matrix (ECM) it has been difficult to establish in situ ACC and polymorph formation mechanisms in organisms. As a result, in vitro experiments [16,17,25,29-33] and theoretical modeling $[16,55,56]$ have provided an alternative means of understanding ACC and calcium carbonate crystal formation, and it now appears that nucleation may be explained and understood by alternative nucleation theories. The first of these is the non-classical or pre-nucleation cluster theory, where ACC formation results from the assembly of $1-3 \mathrm{~nm}$ ionic $\mathrm{Ca}^{2+}-\mathrm{CO}_{3}{ }^{2-}$ clusters, known as pre-nucleation clusters, during the early stages of the nucleation process (Figure 2) [29-33]. What is intriguing about this theory is that the prenucleation cluster formation and assembly processes have been shown to be very sensitive to $\mathrm{pH}$ and additives [29-32]. Moreover, it has been proposed that ACC can adopt different proto-structures, i.e., short-range structures that correlate to a given 
crystalline polymorphs [33]. Thus, mineral cluster proto-structure may influence polymorph selection during the ACC-to-crystal transformation process either via a dissolution-re-precipitation Ostwald mechanism [54] or solid-state transformation-like pathways [15,16,31]. If true, then the selection of a given polymorph could be determined at early stages of mineral cluster formation by the stabilization of a given proto-structure of ACC [33].

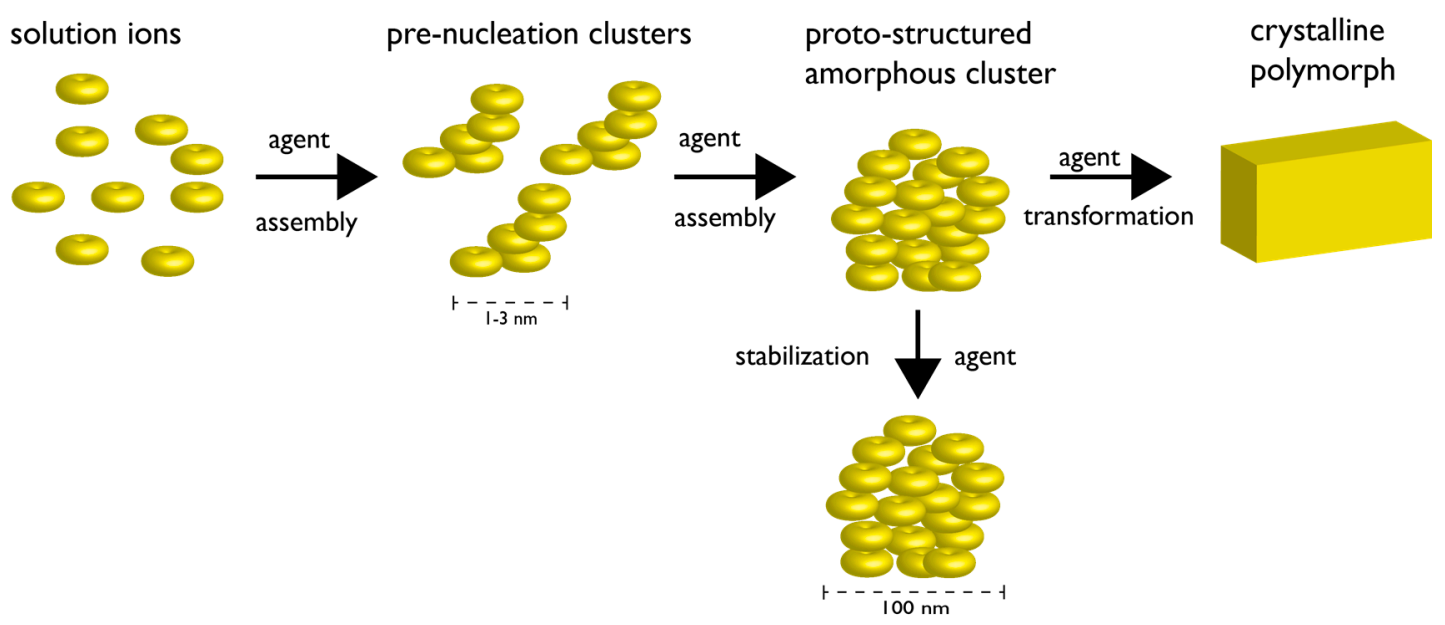

Figure 2. Non-classical nucleation scheme involving pre-nucleation clusters. The formation of pre-nucleation clusters (PNCs) from constituent ions represents the first step towards mineral formation. The PNCs are linear, chain-like ionic polymers (1-3 nm in diameter) that undergo further assembly into amorphous clusters (AC) ( 102 nm in diameter). The AC particle can be stabilized indefinitely by agents, or, can proceed through a transformation mechanism (agent-controlled) and form crystalline solids. In the case where different lattice structures of the same given crystalline compound exist (i.e., polymorph), the choice of polymorph may be dictated at the PNC stage and/or by agents controlling the transformation process. Note that each stage of this non-classical process may be under the control of agent(s) (e.g., proteins, polymers, ions, etc.). Note also that certain steps of the non-classical pathway may be thermodynamically reversible. Adapted from references [27-31].

The second, alternative view on nucleation processes is termed crystallization by particle attachment (CPA) [15]. Here, a crystalline or amorphous mineral forms via the addition of higher-order species such as multi-ion complexes, liquid phases, droplets, gels, oligomers, and fully formed nanoparticles (Figure 3) [15]. In addition to a classical monomer addition pathway [54], in CPA there exist multiple particle-based pathways that eventually lead to the final crystal, and, multiple growth mechanisms can occur simultaneously within a single crystallizing system. The process of particle attachment or assembly can be influenced by several factors, including interfacial or surface free energies. It is argued that the surface free energy is an important determinant in polymorph formation pathways for two reasons: (1) This term affects the magnitude of the free energy barrier for nucleating a given polymorph; and (2) The surface free energy impacts particle size, and thus to form a given polymorph one needs to first nucleate particles with a relatively uniform size distribution within the size range in which that polymorph is stable, then assemble these particles to form the final polymorph [15]. Furthermore, surface free energy can be tuned by extrinsic factors such as: (1) the presence of surfaces, which can reduce interfacial free energy; (2) volume confinement, which can stabilize phases; and (3) the presence of agents, such as small molecules or polymers, which can affect the kinetics of particle formation, particle assembly, and phase stabilities [15]. Thus, if we consider the particle attachment process to be representative of polymorph nucleation, then control over polymorph expression would minimally require the manipulation of both particle formation and the subsequent assembly process. 


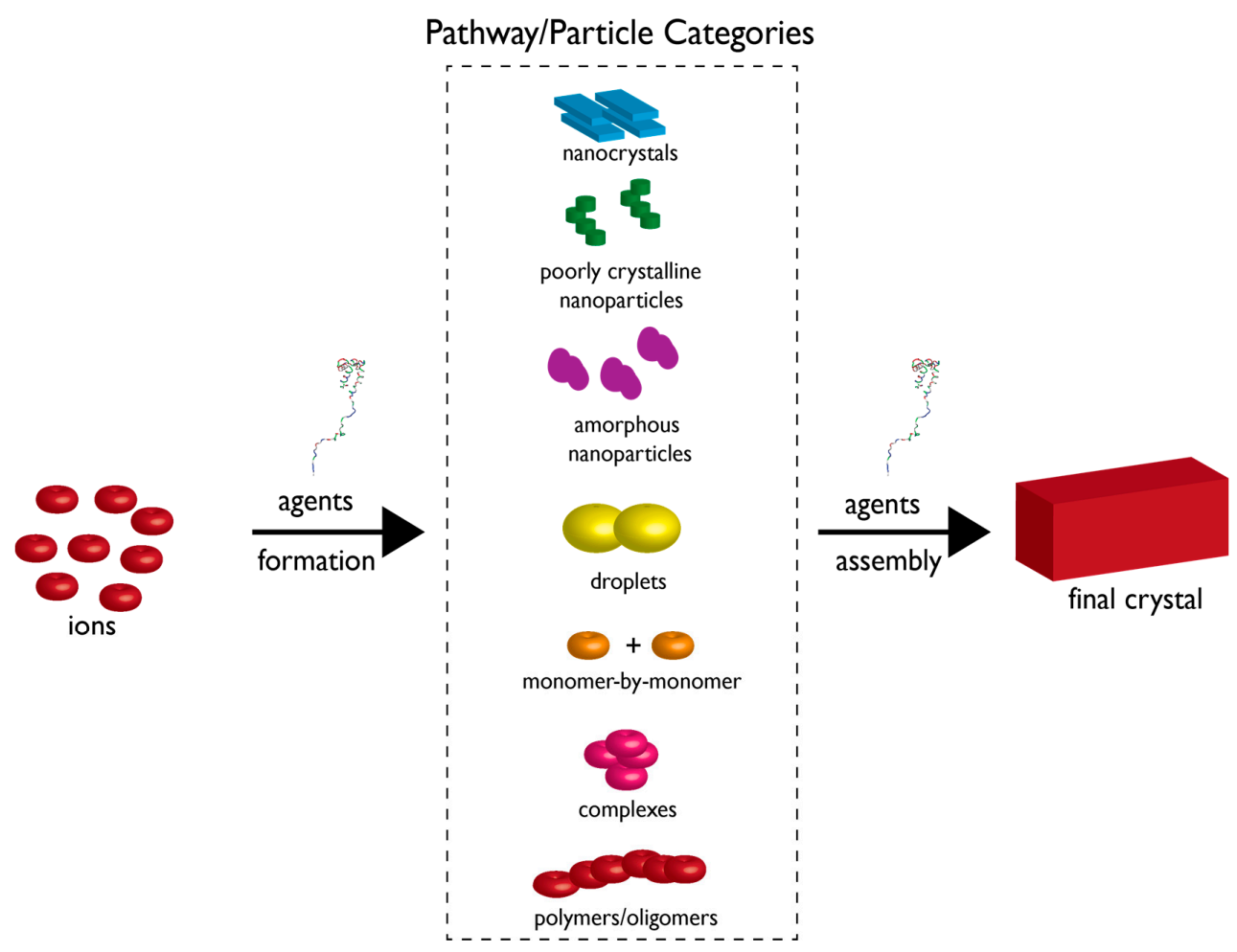

Figure 3. Crystallization by particle attachment (CPA) nucleation scheme. Constituent ions can form several types of particles (described in box region) which can then further assemble into the final crystal polymorph. Thus, the multiple pathways involve ion assembly into a particle type and then further assembly of a given particle type into the crystal. Note that this theory still allows for the classical nucleation scheme which involves monomer-by-monomer addition [54]. Here, formation and assembly pathways are subject to regulation and control by agents or additives. Above the word "agents" we have placed a protein structure to indicate that biomineralization proteins could conceivably perform these proposed assembly tasks. Size of components is not drawn to scale. Adapted from reference [15].

\section{How Biomineralization Proteomes Might Fit into Recently Proposed Nucleation Schemes}

On the assumption that nature does not employ a purely classical nucleation scheme [54] to form calcium carbonate polymorphs, our next task is to take the alternative views on the nucleation process $[15,29-33]$ and determine what role, if any, proteins might play in the polymorph formation process. From the foregoing, it is clear that non-classical [29-33] and CPA [15] pathways to polymorph formation involve multiple steps and processes. Thus, the most efficient path to form calcite, aragonite, or vaterite would depend upon the action of agent(s) that can manipulate key steps along a specific pathway (Figures 2 and 3). This is where biomineralization proteins may be involved. Organisms can regionally and temporally express numerous proteins that cooperatively and synergistically handle tasks within chemical scenarios. As recent studies have shown, invertebrates such as the pearl oyster and sea urchin spicule genomes encode several hundred mineral-associated protein genes apiece [5-8,26-28]. Granted, we would not expect every member of these proteomes to be directly responsible for nucleation and crystal growth, but two possibilities emerge: (1) It is plausible that specialized proteins may be assigned to cover multiple nucleation and crystal growth pathways within a single skeletal element; (2) the formation of a given polymorph is not entrusted to a single protein but spread over multiple proteins, thus ensuring organism survival if one or more proteins experienced a debilitating sequence mutation.

Regarding the non-classical pre-nucleation cluster scheme, it has been proposed that there are several of steps that could be potentially regulated by additives such as proteins, such that a given polymorph crystal is formed: (1) the kinetics of pre-nucleation cluster formation; (2) the assembly 
and stabilization of PNCs into proto-structured ACC; (3) the stabilization and transformation of ACC to a specific polymorph [29-33]. Regarding the CPA scheme, we are confronted with a myriad of possibilities: there may exist multiple assembly pathways to crystal polymorph formation, multiple particle species available for assembly, and multiple growth mechanisms running concurrently [15]. Here, it has been suggested that proteins could lower activation energy barriers to particle assembly, act as stabilizers of liquid-like mineral phases, provide volume confinement for nucleation, simultaneously organize and regulate multiple mechanisms of mineral growth, and so on [15]. In short, each nucleation theory invokes ample control points that could be manipulated by proteins to direct specific polymorph formation.

\section{Protein-Polymorph Formation and Stabilization-What Do We Currently Know?}

Although hypothetical roles and scenarios can be postulated for protein-mediated polymorph formation and stabilization within calcium carbonate nucleation schemes, the more relevant issue is this: what have in vitro and in situ studies revealed about protein participation in the formation of either metastable aragonite or vaterite?

For aragonite, what we must draw from are studies conducted with mollusk shell nacre-associated protein sequences [34-51]. For in vitro-based studies, several different carbonate-based assays have been used to achieve supersaturation conditions necessary for calcium carbonate crystal growth, with no control over $\mathrm{pH}$, and the duration of these nucleation experiments were variable (i.e., from several hours up to 7 days) [36,38,39,41-44,46-51]. Further, some studies utilized $\mathrm{Mg}$ (II) ions in the assay mixture to mimic seawater conditions and promote and stabilize aragonite $[36,44]$. For in situ studies, measurements of aragonite formation were conducted within shells over defined periods of time when certain proteins are expressed or introduced into the shell environment $[34,35,37,40,45]$. In both sets of studies aragonite formation was confirmed in the presence of multiple nacre proteins [34-51]. In addition, some nacre proteins exhibited the ability to inhibit calcite growth $[41,46-48]$ or induce metastable vaterite formation as well $[48,50,51]$.

In comparison to the aragonite studies, there have been fewer published studies that examine the role of proteins in metastable vaterite formation [48,52,53], most likely because of fewer organisms utilizing this polymorph over calcite or aragonite $[52,53,57]$. These studies were in vitro in nature and utilized corresponding calcium carbonate mineralization assays as described for aragonite studies [48,52,53]. Again, as per the aragonite studies, these studies confirmed the formation of metastable vaterite crystals in the presence of the proteins under investigation $[48,52,53]$.

But what do these protein-polymorph studies tell us about the mechanism(s) by which proteins control polymorph formation on their own? Unfortunately, very little. The major reason for this is the lack of standardization: even though conditions for studying non-classical nucleation schemes were published nearly 8 years ago [30] there are few examples in the protein literature that utilize these methods of generating ion supersaturation and subsequent nucleation. Further, many studies relied on different ion concentration levels, control conditions, time periods, temperatures, $\mathrm{pH}$ values, and most importantly, protein quantities, in their assay experiments [34-53]. Typically, in most cases protein quantities have been reported as mass/volume values [34-45,52,53] rather than mole values [46-51], and this lack of standardization prevents cross-comparisons between protein studies. Thus, with all the published experimental variations, it is almost impossible to quantitatively compare the published nucleation results obtained with protein " $\mathrm{A}$ " from one study with protein " $\mathrm{B}$ " of another study. As a result, we cannot effectively piece together the information required to identify a polymorph formation mechanism.

The other important issue regarding past protein-polymorph studies is the intent: These studies focused exclusively on a "yes or no" outcome-i.e., did aragonite or vaterite form [34-53]?-rather than monitor the stepwise or temporal process of polymorph formation that is a prerequisite for mechanism development. These studies confirm that certain calcium carbonate polymorphs do form when proteins are present [34-53], but tell us nothing about how this process occurs, particularly 
within non-classical nucleation [29-33] or CPA [15] schemes. This leaves us at an impasse regarding the verification of protein-mediated polymorph formation.

\section{Moving towards More Informative Studies}

If we are to understand how proteins might control the polymorph selection and stabilization processes, then we need to move towards away from random, non-complementary studies [34-53] and towards standardized assay systems and methodologies [16,29-33] that place biomineralization proteins within the context of non-classical nucleation and CPA schemes. As an example, recent in vitro studies involving five recombinant mollusk shell nacre-associated proteins [58-66] and ACC-stabilizing sea urchin spicule matrix proteins $[67,68]$ have utilized mineralization assay conditions identical to those employed in non-classical nucleation studies [29-33]. What links these different biomineralization proteins together are two common molecular themes [69,70]: intrinsic disorder, or absence of folding protein structure, and amyloid-like aggregation-prone domains, which promote protein-protein association leading to the formation of protein phases or hydrogels [58-68]. These reported studies utilized mole protein quantities, $\mathrm{Ca}$ (II) potentiometric methods, and parallel mineralization assay systems to study the early and later events in calcite-based calcium carbonate nucleation and monitor the formation and stabilization of PNCs and ACC in a time-dependent fashion. What was discovered was very informative: these proteins are distinguishable in terms of what mineral species or steps in the non-classical scheme they affect (Figure 4) [58-67]. Further, using mineralization assays which overlap with the time periods of the potentiometric titrations and utilize similar solution and supersaturation conditions [58-67] these studies demonstrated that these proteins form hydrogels that can capture, assemble, and organize mineral nanoparticles (Figure 5) [62,65] consistent with CPA theory [15]. The major conclusions one can draw from these studies are the following: (1) nacre [58-66] and sea urchin spicule matrix proteins $[67,68]$ perform seminal tasks that would be critical for eventual polymorph selection and stabilization; (2) the functionalities of these six nacre proteins [58-65] are consistent with either non-classical [29-33] or CPA [16] theories [15]. Note that since these protein assay studies were calcite-based, there were no opportunities to study metastable aragonite or vaterite formation and stabilization. However, adjustment of in vitro assay and potentiometric conditions should allow these types of studies to move forward, and thus polymorph-specific studies under controlled conditions with defined protein content will be accomplished.

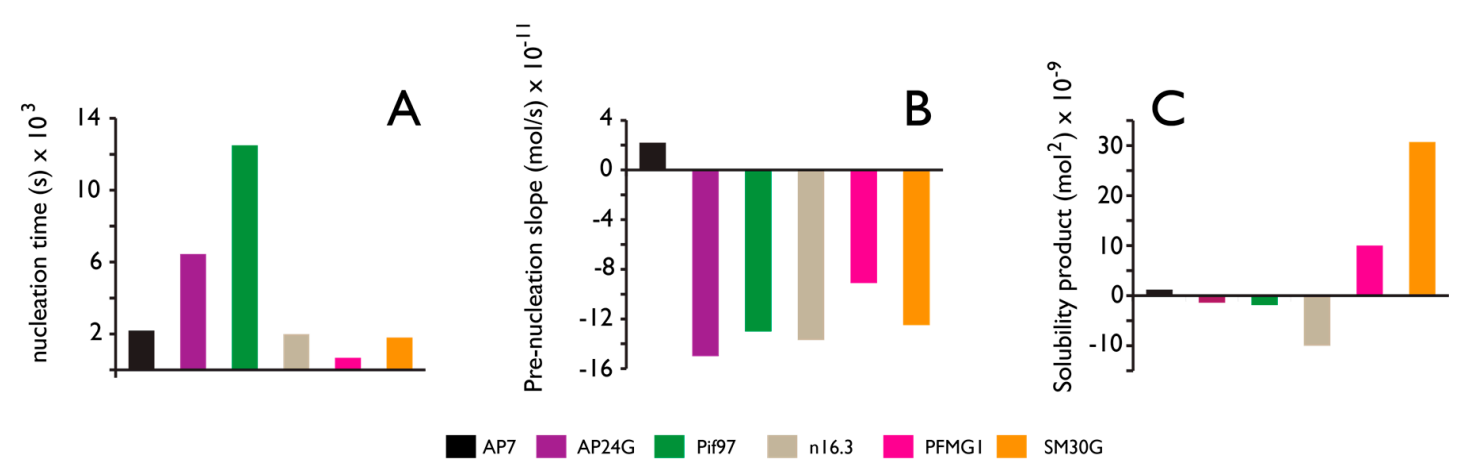

Figure 4. Comparative $\mathrm{Ca}$ (II) potentiometric datasets obtained from nacre (AP7, AP24G, Pif97, n16.3, PFMG1) and sea urchin spicule matrix (SM30G) proteins. All datasets are normalized relative to protein-deficient controls and were conducted at $\mathrm{pH}$ 9.0. Quantities of protein tested ranged from $500 \mathrm{nM}$ to $1 \mu \mathrm{M}$. (A) Nucleation time refers to the time required for PNC formation; (B) "Prenucleation slope" refers to the slope of the linear prenucleation regime in each titration curve. Here, negative value indicates PNC stabilization; positive value indicates PNC destabilization; (C) Solubility product after nucleation. Negative values indicate the presence of less soluble, possibly crystalline phase; positive values reflect transient stabilization of ACC. Data takes from references [58-67]. 


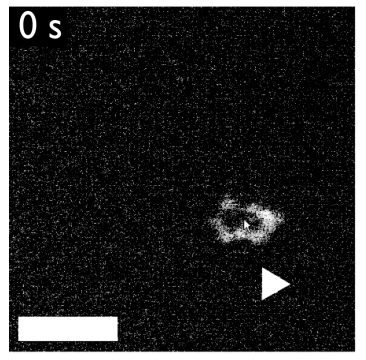

$110 \mathrm{~s}$

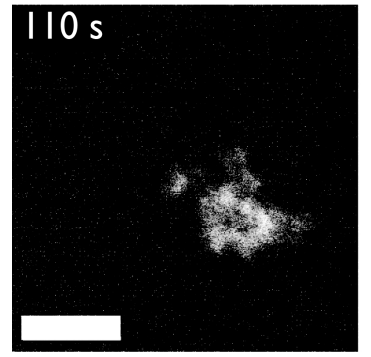

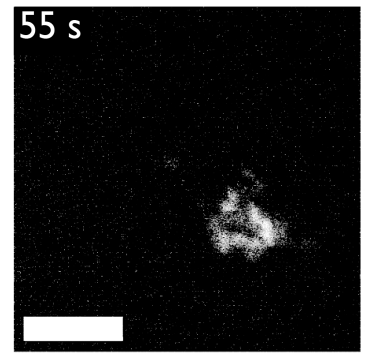

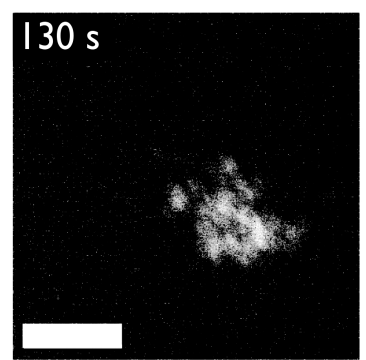

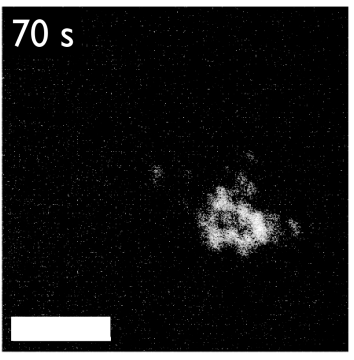

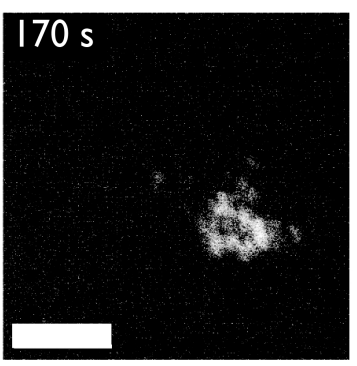

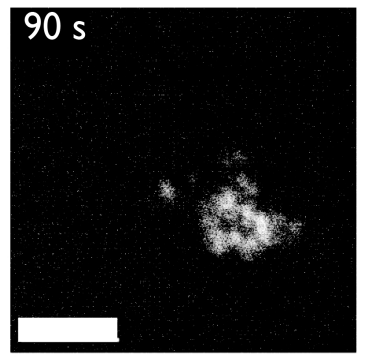

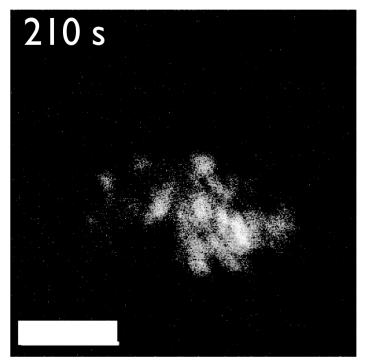

Figure 5. An example of protein-mediated mineral nanoparticle attachment: Scanning Transmission Electron Microscopy (STEM) flowcell video stills of mineral nanodeposits forming in $10 \mathrm{mM}$ calcium carbonate solutions in the presence of $13.3 \mu \mathrm{M}$ Haliotis rufescens abalone shell nacre protein AP7. AP7 is a hydrogelator that forms aggregating gels that contain mineral nanoparticles. The sequence of images starts $45 \mathrm{~min}$ after injection of the calcium solution into the protein-containing flow cell (first frame, denoted as $0 \mathrm{~s}$ ) when mineral nanodeposits are first detected (white arrow, first frame) and nucleation evolves slowly (i.e., $210 \mathrm{~s}$ ). As one can see, mineral particles are assembling from solution, presumably directed by the protein hydrogel. Note the formation of ring-like nanoclusters as time evolves; this would be atypical for a protein-free assay. By comparison, in the protein-deficient experiments mineralization commences $20 \mathrm{~min}$ after injection of the calcium solution and evolves much more rapidly with no evidence of organized particle attachment (data not shown). Scale bars $=100 \mathrm{~nm}$. Taken from reference [62].

Although in vitro studies provide basic insights into polymorph formation, there remains the task of verifying that these processes occur in situ within mineralized tissues where polymorphs are formed. Although it is quite feasible to dissect time- and location-dependent nucleation events in parallel with protein expression, transport, and appearance [35,40,42,43,71-73] it is not yet feasible to correctly monitor, interpret, and integrate PNC, ACC, phase formation, particle assembly and organization simultaneously within the context of protein-specific events in situ. These limitations are primarily technological in scope, meaning that the methods and techniques to obtain this critical information are currently unavailable or do not possess sufficient sensitivity or spatio-temporal resolution to achieve the desired result. Once again, these issues should be resolved in time.

\section{The Next Steps}

We are at a crossroads in biomineralization and nucleation theory. Earlier models [54] which described classical nucleation of polymorphs have undergone a sophisticated evolution towards a multicomponent, multiprocess—based set of theories [15,16,29-33]. Although such theories might seem more complex at the outset, they are quite simple from the biological perspective: they allow for multiple pathways and approaches to achieve a desired mineral phase result specific for a given skeleton and organism. Again, this is where biology shines, for each organism could evolve its own version of nucleation pathway manipulation using specialized proteins [26-28] yet still obey the same thermodynamic laws and limitations [15,16,29-33]. As we are starting to see, a common theme that emerges from proteome studies is that these proteins share common traits, such as intrinsic disorder or unfolded structure [69] and aggregation propensity [69] that leads to protein phase or 
hydrogel formation that provides volume confinement and a pathway to particle assembly and organization [58-67]. Yet, the sequences of these proteins are unalike [58-67] and so genetic variation is permissible and even welcomed in biological organisms so long as specific nucleation goals are being met.

Thus, protein-mediated nucleation and polymorph selection and stabilization could be tweaked for an aragonite, vaterite, or calcite-based organism using a common blueprint-protein disorder and aggregation propensity [69] — that is modified to influence nucleation along a specific pathway, and, to manipulate certain steps within a given pathway. It is hoped that future research, involving standardized conditions and approaches, will firmly establish protein-based mechanisms of polymorph selection and stabilization in nature, and thus facilitate the transfer of this information to materials science and chemistry.

Acknowledgments: Themes concerning nacre proteins were supported by the U.S. Department of Energy, Office of Basic Energy Sciences, Division of Materials Sciences and Engineering under Award DE-FG02-03ER46099. Themes concerning sea urchin proteins were supported by the U.S. Army Research Laboratory and the U.S. Army Research Office under grant number W911NF-16-1-0262. This paper represents contribution number 87 from the Laboratory for Chemical Physics, New York University.

Conflicts of Interest: The author declares no conflict of interest.

\section{References}

1. Wegst, U.G.K.; Bai, H.; Saiz, E.; Tomsia, A.P.; Ritchie, R.O. Bioinspired materials. Nat. Mater. 2015, 14, $23-36$. [CrossRef] [PubMed]

2. Zhang, G.; Li, X. Uncovering aragonite nanoparticle self-assembly in nacre-A natural armor. Cryst. Growth Des. 2012, 12, 4306-4310. [CrossRef]

3. Li, X.; Chang, W.C.; Chao, Y.J.; Wang, R.; Chang, M. Nanoscale structural and mechanical characterization of a natural nanocomposite material: The shell of red abalone. NanoLetters 2004, 4, 613-617. [CrossRef]

4. Sun, J.; Bhushan, B. Hierarchical structure and mechanical properties of nacre: A review. RSC Adv. 2012, 2, 7617-7632. [CrossRef]

5. Berman, A.; Addadi, L.; Kvick, A.; Leiserowitz, L.; Nelson, M.; Weiner, S. Intercalation of sea urchin proteins in calcite: Study of a crystalline composite material. Science 1990, 250, 664-667. [CrossRef] [PubMed]

6. Sea Urchin Genome Sequencing Consortium. The genome of the sea urchin Strongylocentrotus purpuratus. Science 2006, 314, 941-952.

7. Mann, K.; Poustka, A.J.; Mann, M. The sea urchin (Strongylocentrotus purpuratus) test and spine proteomes. Proteome Sci. 2008, 6, 1-10. [CrossRef] [PubMed]

8. Mann, K.; Wilt, F.H.; Poustka, A.J. Proteomic analysis of sea urchin (Strongylocentrotus purpuratus) spicule matrix. Proteome Sci. 2010, 8, 1-12. [CrossRef] [PubMed]

9. Tester, C.C.; Wu, C.H.; Krejci, M.R.; Mueller, L.; Park, A.; Lai, B.; Chen, S.; Sun, C.; Joester, D. Time-resolved evolution of short- and long-range order during the transformation of ACC to calcite in the sea urchin embryo. Adv. Funct. Mater. 2013, 23, 4185-4194. [CrossRef]

10. Politi, Y.; Metzler, R.A.; Abrecht, M.; Gilbert, B.; Wilt, F.H.; Sagi, I.; Addadi, L.; Weiner, S.; Gilbert, P. Transformation mechanism of amorphous calcium carbonate into calcite in the sea urchin larval spicule. Proc. Natl. Acad. Sci. USA 2008, 105, 17362-17366. [CrossRef] [PubMed]

11. Gong, Y.U.T.; Killian, C.E.; Olson, I.C.; Appathurai, N.P.; Amasino, A.L.; Martin, M.C.; Holt, L.J.; Wilt, F.H.; Gilbert, P. Phase transitions in biogenic amorphous calcium carbonate. Proc. Natl. Acad. Sci. USA 2012, 109, 6088-6093. [CrossRef] [PubMed]

12. Drake, J.L.; Mass, T.; Haramaty, L.; Zelzion, E.; Bhattacharya, D.; Falkowski, P.G. Proteomic analysis of skeletal organic matrix from the stony coral Stylophora pistillata. Proc. Natl. Acad. Sci. USA 2013, 110, 3788-3793. [CrossRef] [PubMed]

13. Moya, A.; Luisman, L.; Ball, E.E.; Hayward, D.C.; Grasso, L.C.; Chua, C.M.; Woo, H.N.; Gattuso, J.P.; Forêt, S.; Miller, D.J. Whole transcriptome analysis of the coral Acropora millepora reveals complex responses to $\mathrm{CO}_{2}$-driven acidification during the initiation of calcification. Mol. Ecol. 2012, 21, 2440-2454. [CrossRef] [PubMed] 
14. Goffredo, S.; Vergni, P.; Reggi, M.; Caroselli, E.; Sparla, F.; Levy, O.; Dubinsky, Z.; Falini, G. The skeletal organic matrix from Mediterranean coral Balanophyllia europaea influences calcium carbonate precipitation. PLOS ONE 2011, 6, e22338. [CrossRef] [PubMed]

15. De Yoreo, J.J.; Gilbert, P.U.P.A.; Sommerdijk, N.A.J.M.; Penn, R.L.; Whitelam, S.; Joester, D.; Zhang, H.; Rimer, J.D.; Navrotsky, A.; Banfield, J.F.; et al. Crystallization by particle attachment in synthetic, biogenic, and geologic environments. Science 2015, 349, 498-510. [CrossRef] [PubMed]

16. Wallace, A.F.; Hedges, L.O.; Fernandez-Martinez, A.; Raiteri, P.; Gale, J.D.; Waychunas, G.A.; Whitelam, S.; Banfield, J.F.; De Yoreo, J.J. Liquid-liquid separation in supersaturated $\mathrm{CaCO}_{3}$ solutions. Science 2013, 341, 885-889. [CrossRef] [PubMed]

17. Lee, K.; Wagermaier, W.; Masic, A.; Kommareddy, K.P.; Bennet, M.; Manjubala, I.; Lee, S.W.; Park, S.B.; Cölfen, H.; Fratzl, P. Self-assembly of amorphous calcium carbonate microlens arrays. Nat. Commun. 2012, 3 , 725-727. [CrossRef] [PubMed]

18. Politi, Y.; Arad, T.; Klein, E.; Weiner, S.; Addadi, L. Sea urchin spine calcite forms via a transient amorphous calcium carbonate phase. Science 2004, 306, 1161-1164. [CrossRef] [PubMed]

19. Weiss, I.M.; Tuross, N.; Addadi, L.; Weiner, S. Mollusc larval shell formation: Amorphous calcium carbonate is a precursor phase for aragonite. J. Exp. Zool. 2002, 293, 478-491. [CrossRef] [PubMed]

20. Bernstein, J. Polymorphism-A perspective. Cryst. Growth Des. 2011, 11, 632-650. [CrossRef]

21. Sand, K.K.; Rodriguez-Blanco, M.; Makovicky, E.; Benning, L.G.; Stipp, S.L.S. Crystallization of $\mathrm{CaCO}_{3}$ in water-alcohol mixtures: Spherulitic growth, polymorph stabilization, and morphology change. Cryst. Growth. Des. 2012, 12, 842-853. [CrossRef]

22. Olderoy, M.O.; Xie, M.; Strand, B.L.; Draget, K.I.; Sikorski, P.; Andreassen, J.P. Polymorph switching in the calcium carbonate system by well-defined alginate oligomers. Cryst. Growth Des. 2011, 11, 520-529. [CrossRef]

23. Xiao, J.; Zhu, Y.; Liu, Y.; Liu, H.; Xu, F.; Wang, L. Vaterite selection by chitosan gel: An example of polymorph selection by morphology of biomacromolecules. Cryst. Growth Des. 2008, 8, 2887-2891. [CrossRef]

24. Sun, W.; Jayaraman, S.; Chen, W.; Persson, K.A.; Ceder, G. Nucleation of metastable aragonite $\mathrm{CaCO}_{3}$ in seawater. Proc. Natl. Acad. Sci. USA 2015, 112, 3199-3204. [CrossRef] [PubMed]

25. Kababya, S.; Gal., A.; Kahil, K.; Weiner, S.; Addadi, L.; Schmidt, A. Phosphate-water interplay tunes amorphous calcium carbonate metastability: Spontaneous phase separation and crystallization versus stabilization viewed by solid-state NMR. J. Am. Chem. Soc. 2015, 137, 990-998. [CrossRef] [PubMed]

26. Immel, F.; Gaspard, D.; Marie, A.; Guichard, N.; Cusack, M.; Marin, F. Shell proteome of rhynchonelliform brachiopods. J. Struct. Biol. 2015, 190, 360-384. [CrossRef] [PubMed]

27. Zhang, G.; Fang, X.D.; Guo, X.M.; Li, L.; Luo, R.B.; Xu, F.; Yang, P.C.; Zhang, L.L.; Wang, X.T.; Qi, H.G.; et al. The oyster genome reveals stress adaptation and complexity of shell formation. Nature 2012, 490, 49-54. [CrossRef] [PubMed]

28. Jackson, D.J.; McDougall, C.; Woodcroft, B.; Moase, P.; Rose, R.A.; Kube, M.; Reinhart, R.; Rokhsar, D.S.; Montagnani, C.; Joube, C.; et al. Parallel evolution of nacre building gene sets in mollusks. Mol. Biol. Evol. 2010, 27, 591-608. [CrossRef] [PubMed]

29. Gebauer, D.; Kellermeier, M.; Gale, J.D.; Bergstrom, L.; Cölfen, H. Pre-nucleation clusters as solute precursors in crystallization. Chem. Soc. Rev. 2014, 43, 2348-2371. [CrossRef] [PubMed]

30. Gebauer, D.; Volkel, A.; Cölfen, H. Stable prenucleation of calcium carbonate clusters. Science 2008, 322, 1819-1822. [CrossRef] [PubMed]

31. Gebauer, D.; Cölfen, H. Prenucleation clusters and non-classical nucleation. Nano Today 2011, 6, 564-584. [CrossRef]

32. Demichelis, R.; Raiteri, P.; Gale, J.D.; Quigley, D.; Gebauer, D. Stable prenucleation mineral clusters are liquid-like ionic polymers. Nat. Commun. 2011, 2, 1-12. [CrossRef] [PubMed]

33. Gebauer, D.; Gunawidjaja, P.N.; Ko, J.Y.P.; Bascik, Z.; Aziz, B.; Liu, L.; Hu, Y.; Bergstrom, L.; Tai, C.W.; Sham, T.K.; et al. Proto-calcite and proto-vaterite in amorphous calcium carbonates. Angew. Chem. Int. Ed. 2010, 49, 8889-8891. [CrossRef] [PubMed]

34. Belcher, A.M.; Wu, X.H.; Christensen, R.J.; Hansma, P.K.; Stucky, G.D.; Morse, D.E. Control of crystal phase switching and orientation by soluble mollusk shell proteins. Nature 1996, 381, 56-58. [CrossRef] 
35. Fritz, M.; Belcher, A.M.; Radmacher, M.; Walters, D.A.; Hansma, P.K.; Stucky, G.D.; Morse, D.E.; Mann, S. Flat pearls from biofabrication of organized composites on inorganic substrates. Nature 1994, 371, 49-51. [CrossRef]

36. Su, J.; Zhu, F.; Zhang, G.; Wang, H.; Xie, L.; Zhang, R. Transformation of amorphous calcium carbonate nanoparticles into aragonite controlled by ACCBP. CrystEngComm 2016, 18, 2125-2134. [CrossRef]

37. Thompson, J.B.; Paloczi, G.T.; Kindt, J.H.; Michenfelder, M.; Smith, B.L.; Stucky, G.; Morse, D.E.; Hansma, P.K. Direct observation of the transition from calcite to aragonite growth as induced by abalone shell proteins. Biophys. J. 2000, 79, 3307-3312. [CrossRef]

38. Seto, J.; Picker, A.; Evans, J.S.; Cölfen, H. A nacre protein sequence organizes the mineralization space for polymorph formation. Cryst. Growth Des. 2014, 14, 1501-1505. [CrossRef]

39. Suzuki, M.; Saruwatari, K.; Kogure, T.; Yamamoto, Y.; Nishimura, T.; Kato, T.; Nagasawa, H. An acidic matrix protein, Pif, is a key macromolecule for nacre formation. Science 2009, 325, 1388-1390. [CrossRef] [PubMed]

40. Xiang, L.; Su, J.; Zheng, J.G.; Liang, J.; Zhang, G.; Wang, H.; Xie, L.; Zhang, R. Patterns of expression in the matrix proteins responsible for nucleation and growth of aragonite crystals in flat pearls of Pinctada fucata. PLoS ONE 2013, 8, e66564. [CrossRef]

41. Yan, Z.; Jing, G.; Gong, N.; Li, C.; Zhou, Y.; Xie, L.; Zhang, R. N40, a novel nonacidic matrix protein from pearl oyster nacre, facilitates nucleation of aragonite in vitro. Biomacromolecules 2007, 8, 3597-3601. [CrossRef] [PubMed]

42. Jiao, Y.; Wang, H.; Du, X.; Zhao, X.; Wang, Q.; Huang, R.; Deng, R. Dermatopontin, a shell matrix protein gene from pearl oyster Pinctada martensii, participates in nacre formation. Biochem. Biophys. Res. Commun. 2012, 425, 679-693. [CrossRef] [PubMed]

43. Ma, Z.; Huang, J.; Sun, J.; Wang, G.; Li, C.; Xie, L.; Zhang, R. A novel extrapallial fluid protein controls the morphology of nacre lamellae in the pearl oyster, Pinctada fucata. J. Biol. Chem. 2007, 282, 23253-23263. [CrossRef] [PubMed]

44. Samata, T.; Hayashi, N.; Kono, M.; Hagesawa, K.; Horita, C.; Akera, S. A new matrix protein family related to the nacreous layer formation of Pinctada fucata. FEBS Lett. 1999, 462, 225-229. [CrossRef]

45. Falini, G.; Albeck, S.; Weiner, S.; Addadi, L. Control of aragonite or calcite polymorphism by mollusk shell macromolecules. Science 1996, 271, 67-69. [CrossRef]

46. Amos, F.F.; Evans, J.S. AP7, a partially disordered pseudo C-RING protein, is capable of forming stabilized aragonite in vitro. Biochemistry 2009, 48, 1332-1339. [CrossRef] [PubMed]

47. Ponce, C.B; Evans, J.S. Polymorph crystal selection by n16, an intrinsically disordered nacre framework protein. Cryst. Growth Des. 2011, 11, 4690-4696. [CrossRef]

48. Amos, F.F.; Ponce, C.B.; Evans, J.S. Formation of framework nacre polypeptide supramolecular assemblies that nucleate polymorphs. Biomacromolecules 2011, 12, 1883-1890. [CrossRef] [PubMed]

49. Metzler, R.A.; Evans, J.S.; Kilian, C.E.; Zhou, D.; Churchill, T.H.; Appathurai, P.N.; Coppersmith, S.N.; Gilbert, P.U.P.A. Lamellar self-assembly and aragonite polymorph selection by a single intrinsically disordered protein fragment. J. Am. Chem. Soc. 2010, 132, 6329-6334. [CrossRef] [PubMed]

50. Keene, E.C.; Evans, J.S.; Estroff, L.A. Matrix interactions in biomineralization: Aragonite nucleation by an intrinsically disordered nacre polypeptide, $\mathrm{n} 16 \mathrm{~N}$, associated with a $\beta$-chitin substrate. Cryst. Growth Des. 2010, 10, 1383-1389. [CrossRef]

51. Amos, F.F.; Destine, E.; Ponce, C.B.; Evans, J.S. The N- and C-terminal regions of the pearl-associated EF Hand protein, PFMG1, promote the formation of the aragonite polymorph in vitro. Cryst. Growth Des. 2010, 10, 4211-4216. [CrossRef]

52. Natoli, A.; Wiens, M.; Schroder, H.C.; Stifanic, M.; Batel, R.; Soldati, A.L.; Jacob, D.E.; Muller, W.E.G. Bio-vaterite formation by glycoproteins from freshwater pearls. Micron 2010, 41, 359-366. [CrossRef] [PubMed]

53. Wang, Y.Y.; Yao, Q.Z.; Zhou, G.T.; Sheng, Y.M. Formation of vaterite mesocrystals in biomineral-like structures and implication for biomineralization. Cryst. Growth Des. 2015, 15, 1714-1725. [CrossRef]

54. Kalikmanov, V.I. Nucleation Theory in Lecture Notes in Physics; Springer Science+Business Media: Dordrecht, The Netherlands, 2013; Volume 860, pp. 17-41.

55. Bano, A.M.; Rodger, P.M.; Quigley, D. New insight into the stability of $\mathrm{CaCO}_{3}$ surfaces and nanoparticles via molecular simulation. Langmuir 2014, 30, 7513-7521. [CrossRef] [PubMed] 
56. Singer, J.W.; Yazaydin, A.O.; Kirkpatrick, R.J.; Bowers, G.M. Structure and transformation of amorphous calcium carbonate: A solid-state 43Ca NMR and computational molecular dynamics investigation. Chem. Mater. 2012, 24, 1828-1836. [CrossRef]

57. Ren, D.; Albert, O.; Sun, M.; Muller, W.E.G.; Feng, Q. Primary cell culture of fresh water Hyriopsis comingii mantle/pearl sac tissues and its effect on calcium carbonate mineralization. Cryst. Growth Des. 2014, 14, 1149-1157. [CrossRef]

58. Chang, E.P.; Roncal-Herrero, T.; Morgan, T.; Dunn, K.E.; Rao, A.; Kunitake, J.A.M.R.; Lui, S.; Bilton, M.; Estroff, L.A.; Kröger, R.; et al. Synergistic biomineralization phenomena created by a nacre protein model system. Biochemistry 2016, 55, 2401-2410. [CrossRef] [PubMed]

59. Chang, E.P.; Perovic, I.; Rao, A.; Cölfen, H.; Evans, J.S. Insect cell glycosylation and its impact on the functionality of a recombinant intracrystalline nacre protein, AP24. Biochemistry 2016, 55, 1024-1035. [CrossRef] [PubMed]

60. Chang, E.P.; Evans, J.S. Pif97, a von Willebrand and Peritrophin biomineralization protein, organizes mineral nanoparticles and creates intracrystalline nanochambers. Biochemistry 2015, 54, 5348-5355. [CrossRef] [PubMed]

61. Chang, E.P.; Williamson, G.; Evans, J.S. Focused ion beam tomography reveals the presence of micro-, meso-, and macroporous intracrystalline regions introduced into calcite crystals by the gastropod nacre protein AP7. Cryst. Growth Des. 2015, 15, 1577-1582. [CrossRef]

62. Perovic, I.; Chang, E.P.; Verch, A.; Rao, A.; Cölfen, H.; Kröger, R.; Evans, J.S. An oligomeric C-RING nacre protein influences pre-nucleation events and organizes mineral nanoparticles. Biochemistry 2014, 53, 7259-7268. [CrossRef] [PubMed]

63. Chang, E.P.; Russ, J.A.; Verch, A.; Kröger, R.; Estroff, L.A.; Evans, J.S. Engineering of crystal surfaces and subsurfaces by an intracrystalline biomineralization protein. Biochemistry 2014, 53, 4317-4319. [CrossRef] [PubMed]

64. Chang, E.P.; Russ, J.A.; Verch, A.; Kröger, R.; Estroff, L.A.; Evans, J.S. Engineering of crystal surfaces and subsurfaces by framework biomineralization protein phases. CrystEngComm 2014, 16, 7406-7409. [CrossRef]

65. Perovic, I.; Chang, E.P.; Lui, M.; Rao, A.; Cölfen, H.; Evans, J.S. A framework nacre protein, n16.3, self-assembles to form protein oligomers that participate in the post-nucleation spatial organization of mineral deposits. Biochemistry 2014, 53, 2739-2748. [CrossRef] [PubMed]

66. Perovic, I.; Mandal, T.; Evans, J.S. A pseudo EF-hand pearl protein self-assembles to form protein complexes that amplify mineralization. Biochemistry 2013, 52, 5696-5703. [CrossRef] [PubMed]

67. Jain, G.; Pendola, M.; Rao, A.; Cölfen, H.; Evans, J.S. A model sea urchin spicule matrix protein self-associates to form mineral-modifying hydrogels. Biochemistry 2016, 55, 4410-4421. [CrossRef] [PubMed]

68. Rao, A.; Seto, J.; Berg, J.K.; Kreft, S.G.; Scheffner, M.; Cölfen, H. Roles of larval sea urchin spicule SM50 domains in organic matrix self-assembly and calcium carbonate mineralization. J. Struct. Biol. 2013, 183, 205-215. [CrossRef] [PubMed]

69. Evans, J.S. Identification of intrinsically disordered and aggregation-Promoting sequences within the aragonite-associated nacre proteome. Bioinformatics 2012, 28, 3182-3185. [CrossRef] [PubMed]

70. Evans, J.S. "Liquid-like" biomineralization protein assemblies: A key to the regulation of non-classical nucleation. CrystEngComm 2013, 15, 8388-8394. [CrossRef]

71. Yan, F.; Jiao, Y.; Deng, Y.; Du, X.; Huang, R.; Wang, Q.; Chen, W. Tissue inhibitor of metalloprotease gene from pearl oyster Pinctada martensii participates in nacre formation. Biochem. Biophys. Res. Commun. 2014, 450, 300-305. [CrossRef] [PubMed]

72. Liu, H.L.; Liu, S.F.; Ge, Y.J.; Liu, J.; Wang, X.Y.; Xie, L.P.; Zhang, R.; Wang, Z. Indentification and characterization of a biomineralization related gene PFMG1 highly expresses in the mantle of Pinctada fucata. Biochemistry 2007, 46, 844-851. [CrossRef] [PubMed]

73. Yan, Z.; Fang, Z.; Ma, Z.; Deng, J.; Li, S.; Xie, L.; Zhang, R. Biomineralization: Functions of calmodulin-like protein in the shell formation of pearl oyster. Biochim. Biophys. Acta 2007, 1770, 1338-1344. [CrossRef] [PubMed]

(C) 2017 by the author. Licensee MDPI, Basel, Switzerland. This article is an open access article distributed under the terms and conditions of the Creative Commons Attribution (CC BY) license (http:/ / creativecommons.org/licenses/by/4.0/). 